\title{
Autologous Blood Transfusion Enhances Exercise Performance-Strength of the Evidence and Physiological Mechanisms
}

\author{
Sara Amalie Solheim ${ }^{1,2} \mathbb{D}$, Jacob Bejder ${ }^{1} \mathbb{D}$, Andreas Breenfeldt Andersen ${ }^{1} \mathbb{D}$, Jakob Mørkeberg ${ }^{2}$ and \\ Nikolai Baastrup Nordsborg ${ }^{1 *}$ (D)
}

\begin{abstract}
This review critically evaluates the magnitude of performance enhancement that can be expected from various autologous blood transfusion (ABT) procedures and the underlying physiological mechanisms. The review is based on a systematic search, and it was reported that 4 of 28 studies can be considered of very high quality, i.e. placebocontrolled, double-blind crossover studies. However, both high-quality studies and other studies have generally reported performance-enhancing effects of ABT on exercise intensities ranging from $~ 70$ to $100 \%$ of absolute peak oxygen uptake $\left(\mathrm{VO}_{2 \text { peak }}\right)$ with durations of 5-45 min, and the effect was also seen in well-trained athletes. A linear relationship exists between $\mathrm{ABT}$ volume and change in $\mathrm{VO}_{2 \text { peak. }}$. The likely correlation between $\mathrm{ABT}$ volume and endurance performance was not evident in the few available studies, but reinfusion of as little as $135 \mathrm{~mL}$ packed red blood cells has been shown to increase time trial performance. Red blood cell reinfusion increases endurance performance by elevating arterial oxygen content $\left(C_{a} O_{2}\right)$. The increased $C_{a} \mathrm{O}_{2}$ is accompanied by reduced lactate concentrations at submaximal intensities as well as increased $\mathrm{VO}_{2 \text { peak. }}$. Both effects improve endurance performance. Apparently, the magnitude of change in haemoglobin concentration ([Hb]) explains the increase in $\mathrm{VO}_{2 \text { peak }}$ associated with ABT because blood volume and maximal cardiac output have remained constant in the majority of ABT studies. Thus, the arterial-venous $\mathrm{O}_{2}$ difference during exercise must be increased after reinfusion, which is supported by experimental evidence. Additionally, it remains a possibility that ABT can enhance repeated sprint performance, but studies on this topic are lacking. The only available study did not reveal a performance-enhancing effect of reinfusion on $4 \times 30$ s sprinting. The reviewed studies are of importance for both the physiological understanding of how ABT interacts with exercise capacity and in relation to anti-doping efforts. From an antidoping perspective, the literature review demonstrates the need for methods to detect even small ABT volumes.
\end{abstract}

Keywords: Phlebotomy, Transfusion, Arterial oxygen content, Maximal oxygen uptake, Maximal cardiac output, Anti-doping

\section{Key Points}

- Autologous blood transfusion increases exercise performance over a broad range of exercise intensities and durations.

- The exact relationship between performance increase and transfusion volume cannot be established due to a lack of studies. Even low-

\footnotetext{
* Correspondence: nbn@nexs.ku.dk

'Department of Nutrition, Exercise and Sport Sciences, University of Copenhagen, Universitetsparken 13, 2100 Copenhagen, Denmark Full list of author information is available at the end of the article
}

volume $(135 \mathrm{~mL})$ transfusions increase exercise performance.

- Autologous blood transfusion increases maximal oxygen uptake corresponding to the augmented haemoglobin concentration, whereas maximal cardiac output appears unaffected.

\section{Background \\ One of the first studies of how autologous blood transfu- sions (ABTs) affect exercise performance was completed in 1960 and demonstrated that sustainable power output at a heart rate of $170 \mathrm{bpm}$ is impaired by $\sim 8 \%$ after}


phlebotomy of $\sim 600 \mathrm{~mL}$ and increases by $\sim 4 \%$ after reinfusion of the refrigerated whole blood [1]. Since then, several studies have confirmed ABT to enhance exercise performance in various modes and durations [1-16]. However, ABT is associated with health risks (i.e. bacterial contamination, haemolysis, and allergic reactions) [17] and is against the spirit of sport. Therefore, the use of $\mathrm{ABT}$ is prohibited in competitive sports [18] and has been since 1986.

The hitherto-performed ABT studies have never been critically reviewed with a strong focus on research methodology, although the performance-enhancing effect of ABT appears well established and is in agreement with solid physiological principles. Important factors for study interpretation include number of participants, inclusion of controlled trials, blinding, transfusion volume, storage time, storage method, and exercise protocol. Considering the strengths and weaknesses of the existing studies is important not only for the physiological understanding of how ABT interacts with exercise capacity but also for anti-doping efforts, where knowledge of expected effects helps target and prioritize in-competition and out-ofcompetition testing. Thus, the present review aims to evaluate the magnitude of performance enhancement from various $\mathrm{ABT}$ procedures as well as to address the existing knowledge of the associated physiological mechanisms.

A systematic search for peer-reviewed publications was performed at http://www.pubmed.com using the following query: (((autologous blood transfusion) OR (red blood cell transfusion)) AND (performance OR exercise)). In addition, the retrieved reference lists were examined for unidentified studies. The literature search was terminated in January 2019. The exclusion criteria were studies published as abstracts only, studies on patients, and studies investigating the combination of ABT and high altitude acclimatization because altitude acclimatization may enhance performance [19]. In total, 28 research articles were included (Table 1).

\section{Effect of ABT on Human Exercise Performance}

\section{Intensity, Duration, and Training Status}

The following section considers the importance of exercise intensity, exercise duration, and participants' training status for the effect of ABT on human performance. In one of the first studies to address ABT's effect on human exercise performance, time to exhaustion (TTE) lasting 5 min increased $23 \%$ following reinfusion with $800 \mathrm{~mL}$ refrigerated packed red blood cells (RBCs) collected 4 weeks earlier [13]. The TTE was determined from treadmill running at a constant grade with a speed requiring maximal oxygen uptake $\left(\mathrm{VO}_{2 \text { peak }}\right)$. Likewise, TTE lasting $\sim 6 \mathrm{~min}$ increased by $\sim 25 \%$ compared to before collection when four participants received cold- stored packed RBCs from the sequential donation of $1200 \mathrm{~mL}$ of blood obtained $\sim 30$ days earlier [13]. However, the small sample size, the lack of a control group, and the non-blinded design preclude firm conclusions. When applying a double-blind, placebo-controlled crossover design and 7-11 weeks cryopreservation, performance was enhanced by $\sim 30 \%$ in a TTE lasting $~ 10$ min [10] and by $3 \%$ in 5 mile and $10 \mathrm{~km}$ time trials (TT) $[9,14]$ in well-trained males receiving a reinfusion of RBCs reconstituted to normal haematocrit (Hct) from a $\sim 900 \mathrm{~mL}$ donation. Generally, the high-quality ABT studies report enhanced performance by $\sim 3-5 \%$ compared with pre-reinfusion performance in time trials lasting 30-45 $\min [7,9,14]$ and that TTE is prolonged by $\sim 30 \%$ in a test lasting $\sim 10 \mathrm{~min}[10]$. It is of note that all the best controlled studies investigated well-trained male athletes (Table 1). Moreover, the performance enhancement was evident when evaluated a few days before and after reinfusion [1, 3-11, 13-16]. Importantly, both reinfusion of cryopreserved RBCs and reinfusion of cold-stored RBCs improve exercise performance irrespective of total haemoglobin mass recovery, which may be incomplete, especially in the context of cold storage, where $\leq 4$ weeks elapse between donation and reinfusion $[1,6-8,13,30]$. In support of the performanceenhancing effect of ABT, both high-quality and lowquality studies generally report that blood reinfusion improves exercise performance in tasks lasting from $\sim 5$ to $\sim 45 \mathrm{~min}$, which corresponds to exercise intensities of approximately 70 to $\sim 100 \%$ of $\mathrm{VO}_{2 \text { peak }}$. Furthermore, performance enhancement has been observed in both untrained and well-trained men (Table 1). Notably, the only study enrolling only women [5] also reported improved performance, but a lack of studies addressing a possible sex-specific effect is apparent. In relative terms, the effect of ABT in open-ended performance tests, i.e. TTE tests with a relatively short duration, appears superior, with an improvement range of $16-40 \%$, to closeended tests, i.e. TT tests of longer duration, with an improvement range of 3-5\% (Table 1).

\section{ABT Volume and Physiological Effects}

In the present section, it is considered whether a dosedependent effect of ABT exists on maximal aerobic power and exercise performance.

\section{Standard-Volume, High-Volume, and Low-Volume ABT}

Reinfusion of cold-stored RBCs from $450-500 \mathrm{~mL}$ donations, herein termed 'standard-volume ABT', enhances $3 \mathrm{~km}$ treadmill time-trial performance by $\sim 5 \%$ in moderately trained men [6] and TTE at maximal aerobic workload by $\sim 40 \%$ in untrained men [16]. However, in some studies, reinfusion of $450 \mathrm{~mL}$ whole blood or $200 \mathrm{~mL}$ packed $\mathrm{RBCs}$ reconstituted with 


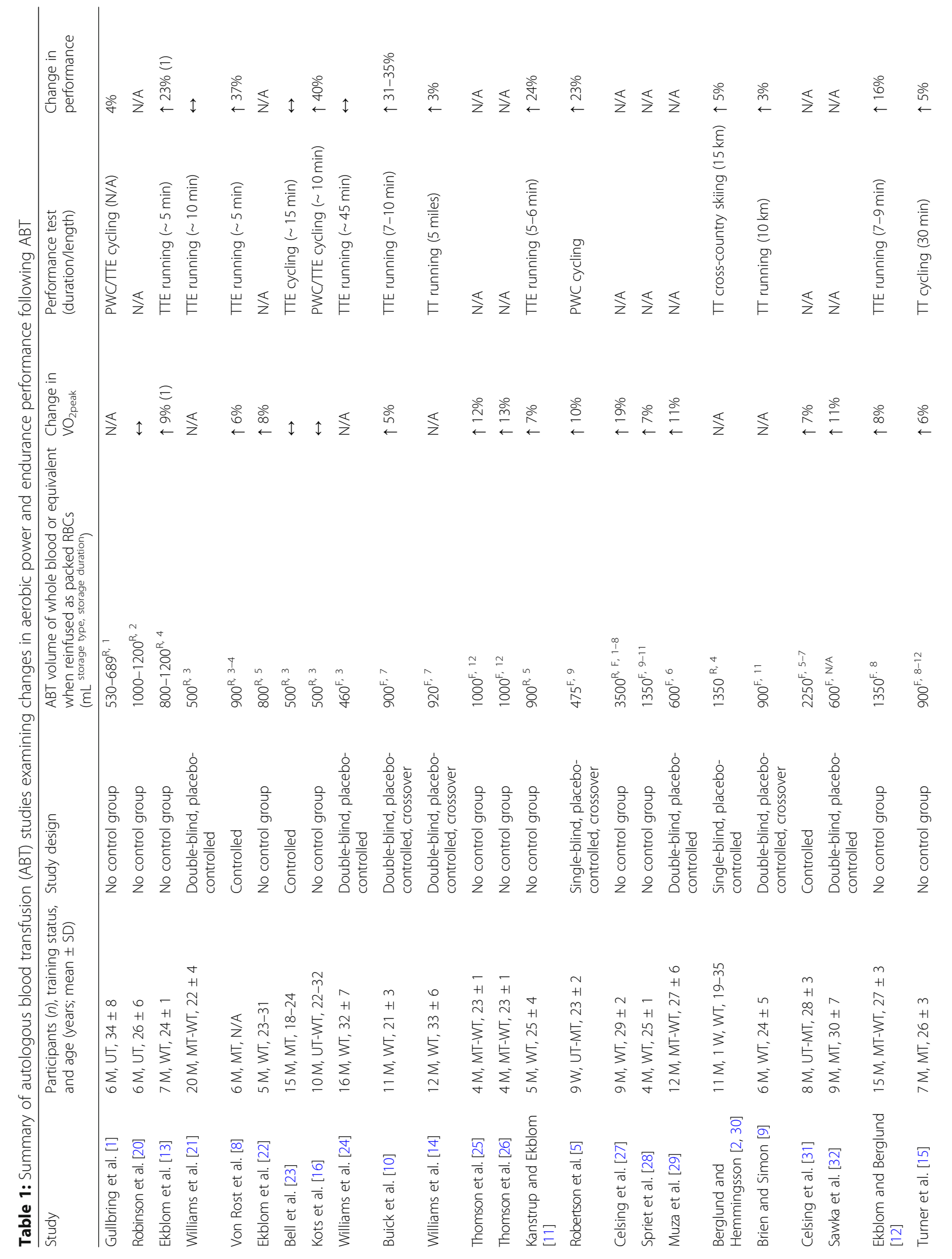




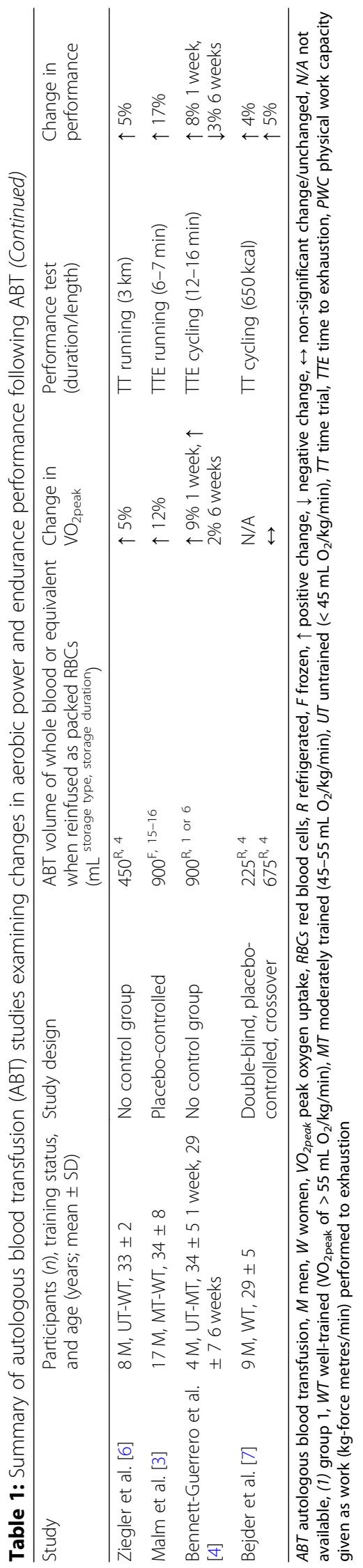


physiological saline to a normal Hct did not result in detectable performance gains in moderately trained to well-trained males, neither following cryopreservation $[24,28]$ nor after cold storage [21, 23]. Five of eight studies investigating reinfusion of a 'standard-volume' corresponding to $\sim 500 \mathrm{~mL}$ reported improved performance, and the three negative findings must be interpreted cautiously (Table 1). There are several possible explanations why some studies have not observed an effect of a single standard-volume autologous reinfusion on $\mathrm{VO}_{2 \text { peak }}$ or performance. First, the precision and random variation in the physiological measurements may mask performance-relevant increases. This explanation seems likely since inclusion of, for example, four subjects yields a detection limit for changes in absolute $\mathrm{VO}_{2 \text { peak }}$ of $\sim 6 \%$ when assuming a measurement error of 3\% [33]. Moreover, Bell and co-workers [23] did not observe improved TTE, which appears to be likely related to variation in the small group of 5 subjects. Indeed, a numerical increase of $>20 \%$ in TTE was apparent in the ABT group, but unfortunately, no data on variation was reported for this outcome variable. Second, RBC storage lesions and degradation after reinfusion can be of importance since only $\sim 70 \%$ (cold-stored) or $\sim 50 \%$ (cryopreserved) of the haemoglobin $(\mathrm{Hb})$ is preserved after storage [34]. Furthermore, $\sim 25 \%$ of the infused RBCs can be degraded within $24 \mathrm{~h}$ [35], and a detectable effect of $\mathrm{ABT}$ on exercise performance immediately after reinfusion may disappear within a few days. In addition to variations in measures of physiological function and RBC storage lesions, low statistical power for determining subtle performance fluctuations and the selection of time points for performance evaluation are important. For instance, comparison of performance before blood donation and after reinfusion separated by 21 days [21] introduces variation over time as well as a risk of insufficient haemoglobin mass recovery [6, 36]. Indeed, when performance was evaluated prior to phlebotomy and after the reinfusion 21 days later, 10 of 15 participants performed $4-5 \%$ worse [21]. However, this finding appears more likely to be related to an insufficient total haemoglobin $(\mathrm{tHb})$ recovery period and natural fluctuations in exercise capacity than lack of effect of ABT on performance. Clearly, variation in measurements, physiological ability, RBC storage lesions, and RBC degradation as well as study design impact the outcome of studies evaluating the effect of standard-volume ABTs on exercise performance.

The same study design factors as outlined above affect studies of ABT with larger volumes, but the expected higher 'signal-to-noise' ratio reduces the risk of not identifying meaningful effects. However, when interpreting studies of ABT volumes of $\sim 900 \mathrm{~mL}$ or more, which is the case for 17 of the studies listed in Table 1, it must be considered whether the associated increase in blood viscosity lowers maximal cardiac output $\left(\mathrm{Q}_{\max }\right)$ more than increased arterial oxygen content $\left(\mathrm{C}_{\mathrm{a}} \mathrm{O}_{2}\right)$ can compensate for [28] or if it even reduces tissue perfusion. Compromised $\mathrm{Q}_{\max }$ appears of little relevance because an autosomal dominant erythrocytosis carrier (i.e. increased sensitivity to EPO) with a haematocrit of more than $60 \%$ is also an endurance sport Olympic gold medallist [37]. With regard to tissue oxygen delivery, $\mathrm{O}_{2}$ consumption and contractile power of blood-perfused canine gastrocnemius muscles are compromised only when haematocrit is higher than $60 \%$, despite reduced absolute blood flow [38]. In support of the above observations, exercise performance in rodents is optimal at a haematocrit of approximately $60 \%$ [39]. Thus, even markedly elevated blood viscosity after high-volume ABT does not counteract the performance-enhancing effect. This notion is supported by the high-quality studies of $\mathrm{ABT}$ volumes $\sim 900 \mathrm{~mL}$ reporting improved exercise performance in humans $[9,10,14]$.

The possible performance-enhancing effects of ABTs of less than $450 \mathrm{~mL}$, termed 'low-volume ABT' in the present review, have not yet been fully scientifically addressed (Table 1), even though dishonest athletes are suspected to reinfuse low $(\leq 150-200 \mathrm{~mL})$ volumes [40]. To our knowledge, we recently completed the first study on the effect of a low-volume ABT using a randomized, double-blind, placebo-controlled crossover design. We demonstrated that reinfusion with $\sim 135 \mathrm{~mL}$ of coldstored RBCs, corresponding to $\sim 225 \mathrm{~mL}$ of whole blood, is sufficient to increase mean power by $\sim 5 \%$ and reduce elapsed time by $\sim 4 \%$ in a $650 \mathrm{kcal}$ cycling TT [7]. Concomitantly, haemoglobin concentration $([\mathrm{Hb}])$, Hct, and RBC count increased by $3 \%$ compared to their levels 3 days before reinfusion. Hence, even low ABT volumes improve exercise performance.

\section{Is There an ABT Dose-Response Relationship?}

Only a few studies have directly addressed whether ABT volume is decisive for the magnitude of effect on absolute $\mathrm{VO}_{2 \text { peak }}$ and/or exercise performance. One of the earliest studies to investigate the dose-dependency of $\mathrm{ABT}$ on $\mathrm{VO}_{2 \text { peak }}$ applied stepwise reinfusions separated by 2-7 days [28]. Each reinfusion consisted of freezepreserved RBCs, reconstituted with physiological saline to a normal Hct, from $450 \mathrm{~mL}$ whole blood harvested 9-11 weeks earlier [28]. The direct effect on endurance performance was not evaluated, but the primary outcome, $\mathrm{VO}_{2 \text { peak, }}$ surprisingly remained unchanged following the first reinfusion in the four well-trained endurance runners. $\mathrm{VO}_{2 \text { peak }}$ did, however, increase non-significantly $(p>0.05)$ by $\sim 200 \mathrm{~mL} \mathrm{O}_{2} / \mathrm{min}$ 
(4\%) in all four subjects after the second reinfusion, and an additional significant increase to $\sim 340 \mathrm{~mL} \mathrm{O}_{2} / \mathrm{min}$ (7\%) above control was observed after the third reinfusion [28]. Thus, an undetected dose-dependent response may have been apparent. This interpretation is supported by the gradual increase in $\mathrm{VO}_{2 \text { peak }}$ observed with four successive reinfusions of $450 \mathrm{~mL}$ [31]. Thus, the impact of ABT on $\mathrm{VO}_{2 \text { peak }}$ apparently follows a dose-response relationship, as could be expected, although a well-designed study to address this question is lacking.

\section{Does Storage Technique Impact ABT's Effect on Exercise Performance?}

Two main techniques are used for RBC storage: refrigeration (cold storage) or freezing (cryopreservation). In the clinical setting, cold-stored RBCs must be reinfused after 35-42 days, depending on the storage solution, due to increasing storage lesions, whereas cryopreservation allows for storage for up to 30 years [41]. Cold-stored blood appears to be the least probable strategy used by dopers because $20-59$ days is required for full tHb restoration after an $\sim 550 \mathrm{~mL}$ phlebotomy [42] and the effect on $[\mathrm{Hb}]$, and thus performance, may be counteracted by suppressed haemoglobin mass at the time of reinfusion. On the other hand, pre-reinfusion handling of cryopreserved blood is associated with a $20 \%$ larger loss of the initially removed $\mathrm{Hb}$ compared with that of refrigerated blood due to the necessary freeze-thaw-wash process following cryopreservation [34]. Moreover, cryopreservation is more expensive and technically challenging than cold storage. No studies have directly compared the impact of storage technique on performance. However, it is important to note that the evaluation of ABT's effect on exercise capacity requires that the performance evaluation be completed a few days before and after reinfusion, independent of storage technique. Evidently, both storage techniques are able to enhance aerobic performance (Table 1), although the shortcomings of the existing protocols need to be acknowledged.

\section{Study Design Considerations}

Several factors influence the interpretation of $\mathrm{ABT}$ and exercise performance studies. These factors include storage technique, number of participants, inclusion of control trials, blinding procedure, transfusion volume, storage time, exercise protocol, and statistical analyses. From a human performance and anti-doping perspective, the lack of a statistically significant difference following a treatment is of limited value if just one participant gains a competitive advantage. The margin of difference between competitors is small, and a $<1 \%$ effect is of relevance. However, such small changes are difficult to detect in a scientific study. A useful approach in this context could be the evaluation of clinical significance or relevance by reporting effect sizes and minimal clinically important differences [43]. However, the sensitivity issue appears to be of less importance in ABT studies, as a performance-enhancing effect of several percent is present, even when low-volume transfusions are applied [7]. To date, six studies with endurance performance measurements have applied a double-blind, placebo-controlled design with a total of 6-20 participants $[7,9,10,14,21,24]$. All except two [21, 24] of these studies reported improved performance after the reinfusion of autologous blood, which may be ascribed to a sample size of 5 [21] or 8 [24] in each group or variation in the measurements.

\section{Physiological Mechanisms Responsible for the Performance-Enhancing Effect of ABT}

Theoretically, endurance performance is related to $\mathrm{VO}_{2 \text { peak }}$ relative to body weight and the $\%$ of $\mathrm{VO}_{2 \text { peak }}$ that can be sustained during prolonged intense endurance exercise (i.e. $30-40 \mathrm{~min}$ for a $10-\mathrm{km}$ run). However, how does $\mathrm{ABT}$ alter $\mathrm{VO}_{2 \text { peak }}$ and the ability to sustain a high percentage of $\mathrm{VO}_{2 \text { peak }}$ ? In the following sections, the physiological mechanisms that may explain the performance-enhancing effect of ABT are considered.

\section{ABT Increases Maximal Muscular Oxygen Delivery}

Maximal $\mathrm{O}_{2}$ delivery to the contracting limb muscles can be augmented via increased limb blood flow, increased $\mathrm{C}_{\mathrm{a}} \mathrm{O}_{2}$, or both. An increase in maximal limb blood flow requires increased $\mathrm{Q}_{\max }$ or altered blood flow distribution. In the 'Is Maximal Cardiac Output Increased by ABT?' and 'Is Maximal Limb $\mathrm{O}_{2}$ Delivery and Extraction Increased by ABT?' sections, ABT's potential effect on $\mathrm{Q}_{\max }$, limb blood flow, and $\mathrm{C}_{\mathrm{a}} \mathrm{O}_{2}$ is addressed.

\section{Is Maximal Cardiac Output Increased by ABT?}

When maximal exercise with a large muscle mass is performed in normoxia, $\mathrm{Q}_{\max }$ determines the upper limit for $\mathrm{O}_{2}$ delivery to the active muscle groups and thereby becomes the limiting factor for $\mathrm{VO}_{2 \text { peak }}$ in endurancetrained, untrained, and generally healthy individuals [44]. Hence, increasing $\mathrm{Q}_{\max }$ will increase an individual's maximal oxygen uptake and thereby also maximal endurance performance by allowing the individual to exercise at a higher absolute workload, while metabolism remains primarily aerobic [45]. In cross-sectional studies, total blood volume and $\mathrm{tHb}$ are tightly associated with $\mathrm{VO}_{2 \text { peak }}$, whereas $[\mathrm{Hb}]$ is not [46]. In agreement with this idea, $\mathrm{Q}_{\max }$ is closely related to $\mathrm{VO}_{2 \text { peak }}$ [47], and thus, it may be hypothesized that an increased blood volume can increase $\mathrm{Q}_{\max }$ and thereby performance. Indeed, a training-induced expansion of total blood volume appears to be the primary cause of increased 
$\mathrm{VO}_{\text {2peak }}$ via increased $\mathrm{Q}_{\max }$ [48]. Thus, it is tempting to suggest that the ABT-induced increase in $\mathrm{tHb}$ increases $\mathrm{VO}_{2 \text { peak }}$ by increasing $\mathrm{Q}_{\max }$. However, it is important to note that the close association between absolute $\mathrm{VO}_{2 \text { peak }}$ and $\mathrm{tHb}$ when determined in a mixed group of humans is caused primarily by differences in size, including ventricular mass and total blood volume, which defines $\mathrm{Q}_{\max }$ [47], whereas no close association is evident in a homogenous group of athletes [49]. With respect to the effect of blood reinfusion on $\mathrm{VO}_{2 \text { peak }}$, it is important that total blood volume alterations appear to depend on the time of investigation after reinfusion. Total blood volume appears unaffected $\geq 24 \mathrm{~h}$ post-reinfusion of 800 to $2250 \mathrm{~mL}$ of refrigerated whole blood [22] as well as refrigerated [50] or freeze-preserved [31, 32, 50] RBCs reconstituted with physiological saline to a normal Hct. In contrast, $1 \mathrm{~h}$ after reinfusion of packed RBCs from $900 \mathrm{~mL}$ of whole blood, a $5 \%$ increase in total blood volume occurs together with increases in Hct $(2 \%),[\mathrm{Hb}]$ (4\%), $\mathrm{VO}_{2 \text { peak }}(7 \%)$, and cycling performance lasting 3-6 min (24\%) [11]. As such, total blood volume may be unaffected by ABT when determined more than $24 \mathrm{~h}$ after reinfusion due to a rapid compensatory reduction in plasma volume. However, the small number of studies on $\mathrm{ABT}$ and total blood volume and the variances and challenges associated with blood volume determination preclude a firm conclusion.

Reinfusion of autologous blood acutely increases central venous pressure [20], which usually increases $Q_{\max }$ due to an enlarged end-diastolic volume and thereby causes a higher stroke volume and $\mathrm{Q}_{\max }$, according to the Frank-Starling mechanism [51]. However, it is likely that the increased central venous pressure after blood reinfusion is transient $(<24 \mathrm{~h})$ and related to the acute volume expansion, but this remains to be investigated. The most direct approach to determine the effect of $\mathrm{ABT}$ on $\mathrm{Q}_{\max }$ is to measure $\mathrm{Q}_{\max }$. A few studies have directly evaluated $\mathrm{Q}_{\max }$ after blood reinfusion. In 7 males who received RBCs obtained from $900 \mathrm{~mL}$ donations 2-3 months earlier, no difference existed approximately $24 \mathrm{~h}$ after reinfusion in the invasively determined $\mathrm{Q}_{\max }$ of $\sim 22 \mathrm{~L} / \mathrm{min}$, despite a clear $\sim 3 \%$ increase in $\mathrm{VO}_{2 \text { peak }}$ [15]. In 9 women, reinfusion of RBCs from two $450 \mathrm{~mL}$ phlebotomies, conducted 9 and 17 weeks prior, did not alter the $\mathrm{Q}_{\max }$ of $\sim 17 \mathrm{~L} / \mathrm{min}$, as indirectly determined $48 \mathrm{~h}$ later by $\mathrm{CO}_{2}$ rebreathing [5]. Moreover, in four male endurance runners, the reinfusion of RBCs from $900-1350 \mathrm{~mL}$ blood 3-4 weeks after phlebotomy increased $\mathrm{VO}_{2 \text { peak }}$ but only non-significantly increased dye dilution-determined $\mathrm{Q}_{\max }$ from $\sim 28$ to $\sim 33 \mathrm{~L} / \mathrm{min}$ approximately 2 days later [28]. Thus, $\mathrm{Q}_{\max }$ appears unaffected even by reinfusion of rather large volumes and cannot explain the increase in $\mathrm{VO}_{2 \text { peak }}$ and performance after $\mathrm{ABT}$. In this context, it must be noted that determination of $\mathrm{Q}_{\max }$ is technically difficult and associated with variance; therefore, a moderate undetected effect of $A B T$ on $Q_{\max }$ may exist.

Is Maximal Limb $\mathrm{O}_{2}$ Delivery and Extraction Increased by $A B T$ ? Limb blood flow can be as high as $2000-3000 \mathrm{~mL} / \mathrm{min}$ per $\mathrm{kg}$ of muscle [52], and the muscular oxygen uptake capacity is $\sim 600 \mathrm{~mL} / \mathrm{kg} / \mathrm{min}$ in healthy subjects, which is much higher than the amount of $\mathrm{O}_{2}$ supplied during whole-body exercise [53]. Hence, it is evident that limb blood flow is limited by $\mathrm{Q}_{\max }$ during intense whole-body exercise. Thus, if maximal limb blood flow during intense whole-body exercise is increased by reinfusion, this would increase maximal aerobic energy production and thereby performance. However, maximal limb blood flow appears unlikely to increase since $\mathrm{Q}_{\max }$ appears unaffected by reinfusion, as highlighted in the 'Is Maximal Cardiac Output Increased by ABT?' section. In this context, it must be noted that, for example, brain blood flow is primarily dependent on $\mathrm{C}_{\mathrm{a}} \mathrm{O}_{2}$ [54], and therefore, the ABT-induced increase in arterial oxygen content may reduce blood flow to other tissues and organs. As a consequence, it remains a possibility that more blood is redistributed to the exercising muscles and that maximal limb blood flow is marginally increased by RBC reinfusion despite unaltered $\mathrm{Q}_{\max }$. However, this hypothesis remains to be investigated.

Reinfusion of autologous blood is usually $[7,10,13$, $14,28,31,32$, but not always [3], accompanied by elevated $\mathrm{Hct}$ and/or $[\mathrm{Hb}]$ compared to the pre-reinfusion levels. Accordingly, reinfusion increases the $\mathrm{O}_{2}$ carrying capacity per litre of blood, and this has been highlighted in previous reviews as the main physiological mechanism causing enhanced performance following ABT [55]. Indeed, stepwise reinfusions of four blood bags, in eight untrained to moderately trained men, resulted in $\mathrm{VO}_{2 \text { peak }}$ increases of approximately $40 \mathrm{~mL} \mathrm{O}_{2} / \mathrm{min}(1 \%)$, $130 \mathrm{~mL} \mathrm{O} / \mathrm{min} \mathrm{(3 \% ),} 230 \mathrm{~mL} \mathrm{O}_{2} / \mathrm{min}(5 \%)$, and $320 \mathrm{~mL}$ $\mathrm{O}_{2} /$ min $(7 \%)$ and increases in $[\mathrm{Hb}]$ of approximately $4 \%$, $7 \%, 12 \%$, and $13 \%$ from the first to the last reinfusion, respectively [31], as mentioned in the 'Is There an ABT Dose-Response Relationship' section. This result resembles the findings of Spriet and co-workers [28] and corresponds to an approximately $0.47 \%$ increase in $\mathrm{VO}_{2 \text { peak }}$ per $1 \%$ increase in $[\mathrm{Hb}]\left(R^{2}=0.97\right)$ [31]. For the ABTinduced increase in $[\mathrm{Hb}]$ to augment $\mathrm{VO}_{2 \text { peak }}$ without affecting $\mathrm{Q}_{\max }$, the arterial-venous $\mathrm{O}_{2}$ difference (a-v $\mathrm{O}_{2}$ difference) across the exercising muscle groups must be increased. The ABT-induced increase in $\mathrm{C}_{\mathrm{a}} \mathrm{O}_{2}$ and concurrent unchanged $[15,25]$ or reduced [22] mixed venous $\mathrm{O}_{2}$ content $\left(\mathrm{C}_{\mathrm{v}} \mathrm{O}_{2}\right)$ strongly suggest an increased extraction [15] after reinfusion, but the small sample sizes $(n=4-7)$ preclude a firm conclusion. 


\section{ABT, Anaerobic Energy Production, and Metabolic Acidosis Blood Lactate Response to Exercise}

Increased maximal capacity for oxygen delivery likely reduces the anaerobic energy contribution at intensities above $\sim 70 \%$ of $\mathrm{VO}_{2 \text { peak }}$, as illustrated by reduced plasma lactate concentrations ([La]) after ABT measured at the same absolute workload [5]. The reinfusion of RBCs packed saline obtained from phlebotomy of $900 \mathrm{~mL}$ and $1350 \mathrm{~mL}$ whole blood causes a marked reduction in blood lactate values following exercise at $91 \%$ of $\mathrm{VO}_{2 \text { peak }}$ (from $\sim 6 \mathrm{mM}$ before reinfusion to $\sim 2 \mathrm{mM}$ after) and after maximal treadmill running at $100 \%$ of control $\mathrm{VO}_{\text {2peak }}$ (from $\sim 12 \mathrm{mM}$ before to $\sim 5 \mathrm{mM}$ after), concomitant with less disturbed arterial acid-base status 5 min after exercise [28]. Furthermore, blood reinfusion reduces the lactate concentration by approximately $50 \%$ in runners when determined 4 min after submaximal ( 70\% $\left.\mathrm{VO}_{2 \text { peak }}\right)$ treadmill running [10]. In five trained subjects, venesection increased the lactate response to exercise at $\sim 70 \%$ of $\mathrm{VO}_{2 \text { peak }}$ from 6.0 to $7.6 \mathrm{mM}$, while reinfusion reduced lactate to $4.6 \mathrm{mM}$ [22]. This reduction in plasmaborne markers of anaerobic energy contribution during submaximal exercise may increase the $\% \mathrm{VO}_{2 \text { peak }}$ defining the lactate threshold, which is an important determinant of endurance performance $[56,57]$. Since most endurance competitions are not performed at intensities corresponding to $100 \%$ of $\mathrm{VO}_{2 \text { peak }}$, this may be the most important performance-enhancing effect of ABT. However, it should also be acknowledged that some parts, e.g. the final part of a 5000-m or 10,000-m race, a cycling stage with mountain climbs or the like, are likely to elicit $\mathrm{VO}_{2 \text { peak }}$.

\section{Blood pH Response to Exercise}

During intense exercise, anaerobic energy production results in increased plasma hydrogen concentration $\left(\left[\mathrm{H}^{+}\right]\right)$ [58]. Metabolic acidosis is immediately counteracted by hyperventilation, bicarbonate buffering, and nonbicarbonate buffering. The relationship between changes in plasma lactate concentration and $\mathrm{pH}$ is indicated by the in vivo buffer capacity: $\Delta\left[\mathrm{La}^{-}\right] / \Delta \mathrm{pH}$ [59]. RBCs are primary extracellular buffers, and therefore, the total blood buffer capacity depends on the total $\mathrm{RBC}$ volume and the expression of RBC membrane-bound transport systems, such as the $\mathrm{AE} 1$ isoform of the anion-exchange transporter [60, 61] and the MCT1 isoform of the monocarboxylate transporter $\left(\mathrm{La}^{-} / \mathrm{H}^{+}\right.$co-transporter) [61], as well as the enzyme cytoplasmic carbonic anhydrase, which catalyses the reversible hydration of carbon dioxide $\left(\mathrm{CO}_{2}\right) ; \mathrm{CO}_{2}+\mathrm{H}_{2} \mathrm{O}$ (water) $\leftrightharpoons \mathrm{H}_{2} \mathrm{CO}_{3}$ (carbonic acid) $\leftrightharpoons \mathrm{HCO}_{3}{ }^{-}$(bicarbonate) $+\mathrm{H}^{+}[60,61]$. Hence, the RBCs added through ABT have the potential to theoretically improve systemic $\mathrm{pH}$ regulation. However, the possible effect is small since a lowvolume ABT expands the total RBC volume by only a few percent. Nevertheless, the relevance for performance in elite sports with small margins may exist, but this remains to be investigated.

\section{Possible Influence of ABT on Anaerobic Performance and Repeated Sprints?}

The reinfusion of autologous blood increases the maximal muscular oxygen uptake, which is the product of limb blood flow and arterial-venous $\mathrm{O}_{2}$ difference. Blood reinfusions might also increase performance in short, anaerobic, intermittent exercises. Since the aerobic energy provision increases when sprints are repeated $[62,63]$ and the aerobic capacity is important for recovery between sprints [64], it appears likely that repeated sprint ability is improved by blood reinfusion. $\left[\mathrm{La}^{-}\right]$in blood and muscle increases progressively during a $4 \times 30$ s all-out air-braked cycle test in moderately trained males [65]. Additionally, muscle $\mathrm{La}^{-}$accumulates non-linearly during a $2 \times 30 \mathrm{~s}$ allout cycle test at a work load corresponding to $0.075 \times \mathrm{kg}$ of body weight [66] and during $3 \times 30 \mathrm{~s}$ all-out isokinetic cycling at $100 \mathrm{rpm}$ in healthy, recreationally active subjects [58]. The highest impact of blood reinfusion on repeated sprint ability is thus likely to occur in the later sprints. In support of this notion, the level of aerobic ATP provision during sprints has been found to increase progressively as work duration increases $[67,68]$ and as sprints are repeated [62, 63]. Additionally, the potentially improved blood buffer capacity during polycythaemia might contribute to the extracellular $\mathrm{pH}$ defence against lactic acidosis, as outlined in the 'ABT, Anaerobic Energy Production, and Metabolic Acidosis' section [59, 61]. Furthermore, the nature of the recovery between sprints is likely of importance for repeated sprint ability. For example, active recovery is advantageous for the mean power output of sprints when repeated Wingate anaerobic tests are performed [62]. The $\mathrm{O}_{2}$ availability for mitochondria is known to be decisive for creatine phosphate recovery [69], and an ABT-induced increase in $\mathrm{C}_{\mathrm{a}} \mathrm{O}_{2}$ thus appears likely to improve recovery between sprints. Supporting this theory, the $11 \%$ increase in $[\mathrm{Hb}]$, following recombinant human EPO administration, reduces the accumulation of blood $\mathrm{La}^{-}$and plasma hypoxanthine after fifteen 6-s highintensity uphill running sprints with $24 \mathrm{~s}$ of passive rest [70]. Interestingly, in the only study to investigate the effect of ABT on repeated cycling sprint ability, we observed no change in performance after reinfusion, despite an 9\% increase in $\mathrm{tHb}$ and $[\mathrm{Hb}]$ [7]. The combined effect of the reinfusion of $\sim 135$ and $\sim 235 \mathrm{~mL}$ cold-stored RBCs, corresponding to approximately $675 \mathrm{~mL}$ whole blood, did not alter $4 \times 30 \mathrm{~s}$ all-out cycling performance, either when determined as the mean power of all sprints or when evaluated as the mean power in each sprint. The two reinfusions were performed within $\sim 24 \mathrm{~h}$, and the performance was evaluated a few days before the first reinfusion and after the last 
reinfusion, separated by 8 days, as opposed to before the phlebotomy and after the reinfusion. This allowed for the evaluation of ABT-induced changes, although the haematological parameters had not returned to the pre-phlebotomy level at the time of reinfusion. The results suggest that reinfusion with $\sim 370 \mathrm{~mL}$ of packed RBCs does not affect repeated sprint ability as measured by $4 \times 30 \mathrm{~s}$ of all-out cycling interspersed with $4 \mathrm{~min}$ of rest. However, the effect of ABT in other repeated sprint modalities and the effect of larger ABT volumes are unknown.

Overall, the literature is scarce regarding the effects of ABT on repeated sprint performance. Nevertheless, the aforementioned potential effects of ABT in enhancing $\mathrm{O}_{2}$ delivery and blood buffer capacity might be reflected in improvement in fatigue resistance during repeated sprints and thereby enhanced repeated sprint performance in some repeated sprint modalities.

\section{Conclusion}

The literature review revealed that $\mathrm{ABT}$ enhances performance across a span of exercise intensities from $\sim 70$ to $100 \%$ of $\mathrm{VO}_{2 \text { peak }}$ and durations of $5-45 \mathrm{~min}$, and these results were also observed in well-trained athletes. The impact of $\mathrm{ABT}$ on $\mathrm{VO}_{2 \text { peak }}$ apparently exhibits a dose-response relationship, but well-designed studies of likely associated gradual performance effects are lacking. However, reinfusion with as little as $135 \mathrm{~mL}$ packed RBCs increases time-trial performance. Red blood cell reinfusion increases endurance performance by elevating $\mathrm{C}_{\mathrm{a}} \mathrm{O}_{2}$. The increased $\mathrm{C}_{\mathrm{a}} \mathrm{O}_{2}$ is accompanied by increased $\mathrm{VO}_{2 \text { peak }}$ as well as reduced lactate concentrations, i.e. reduced anaerobic energy contribution at submaximal intensities. Both effects improve endurance performance, the latter because most endurance competitions are not performed at intensities corresponding to $100 \%$ of $\mathrm{VO}_{2 \text { peak. }}$. Apparently, the magnitude of change in haemoglobin concentration explains the increase in $\mathrm{VO}_{2 \text { peak }}$ associated with $\mathrm{ABT}$ because blood volume and maximal cardiac output remain constant in the majority of $\mathrm{ABT}$ studies. Thus, the arterial-venous $\mathrm{O}_{2}$ difference during exercise must be increased after reinfusion, which is supported by experimental evidence. Additionally, it remains a possibility that ABT can enhance repeated sprint performance, but studies are lacking. The only available study did not observe a performance-enhancing effect of reinfusion on $4 \times 30 \mathrm{~s}$ sprinting.

The findings are of importance for both the physiological understanding of how ABT interacts with exercise capacity and in relation to anti-doping efforts. From an anti-doping perspective, the literature review demonstrates the need for analytical methods able to detect even minor blood manipulations.

\section{Abbreviations}

[Hb]: Haemoglobin concentration; [La]: Lactic acid concentration; ABT: Autologous blood transfusion; a- $\mathrm{V}_{2}$ difference: Arterial-venous $\mathrm{O}_{2}$ difference; $\mathrm{C}_{\mathrm{a}} \mathrm{O}_{2}$ : Arterial oxygen content; $\mathrm{CO}_{2}$ : Carbon dioxide; $\mathrm{C}_{\mathrm{v}} \mathrm{O}_{2}$ : Mixed venous oxygen content; $\mathrm{EPO}$ : Erythropoietin; $\mathrm{H}^{+}$: Hydrogen ion; $\mathrm{H}_{2} \mathrm{CO}_{3}$ : Carbonic acid; $\mathrm{H}_{2} \mathrm{O}$ : Water; $\mathrm{Hb}$ : Haemoglobin; $\mathrm{HCO}_{3}{ }^{-}$: Bicarbonate; Hct: Haematocrit; La ${ }^{-}$: Lactic acid; $Q_{\text {max }}$ : Maximal cardiac output; RBC: Red blood cell; tHb: Total haemoglobin mass; TT: Time trial; TTE: Time to exhaustion; $\mathrm{VO}_{2 \text { peak: }}$ Peak oxygen uptake

\section{Acknowledgements}

Not applicable.

\section{Authors' Contributions}

SAS and NBN planned the review. SAS retrieved the relevant literature. All authors engaged in drafting and revising the manuscript. All authors approved the final version of the manuscript.

\section{Funding}

During the preparation of this review, Sara Amalie Solheim was funded by Anti Doping Denmark and the Partnership for Clean Competition, Jacob Bejder by the Partnership for Clean Competition, Andreas Breenfeldt Andersen by World Anti-Doping Agency, and Jakob Mørkeberg served as Senior Science Manager at Anti Doping Denmark.

\section{Availability of Data and Materials}

Not applicable. The data that support the findings of this review are available from the cited research articles.

\section{Ethics Approval and Consent to Participate}

Not applicable.

\section{Consent for Publication}

Not applicable.

\section{Competing Interests}

The authors, Sara Amalie Solheim, Jacob Bejder, Andreas Breenfeldt, Jakob Mørkeberg, and Nikolai Baastrup Nordsborg, declare that they have no competing interests.

\section{Author details}

${ }^{1}$ Department of Nutrition, Exercise and Sport Sciences, University of Copenhagen, Universitetsparken 13, 2100 Copenhagen, Denmark. ${ }^{2}$ Anti Doping Denmark, Brøndby, Denmark.

Received: 20 November 2018 Accepted: 25 June 2019

Published online: 08 July 2019

\section{References}

1. Gullbring B, Holmgren A, Sjostrand T, Strandell T. The effect of blood volume variations on the pulse rate in supine and upright positions and during exercise. Acta Physiol Scand. 1960;50:62-71.

2. Berglund $B$, Hemmingsson P. Effect of reinfusion of autologous blood on exercise performance in cross-country skiers. Int J Sports Med. 1987;8:231-3.

3. Malm CB, Khoo NS, Granlund I, Lindstedt E, Hult A. Autologous doping with cryopreserved red blood cells - effects on physical performance and detection by multivariate statistics. PLoS One. 2016;11:e0156157.

4. Bennett-Guerrero E, Lockhart EL, Bandarenko N, Campbell ML, Natoli MJ, Jamnik VK, et al. A randomized controlled pilot study of VO2 max testing: a potential model for measuring relative in vivo efficacy of different red blood cell products. Transfusion. 2017;57:630-6.

5. Robertson RJ, Gilcher R, Metz KF, Caspersen CJ, Allison TG, Abbott RA, et al. Hemoglobin concentration and aerobic work capacity in women following induced erythrocythemia. J Appl Physiol. 1984;57:568-75.

6. Ziegler AK, Grand J, Stangerup I, Nielsen HJ, Dela F, Magnussen K, et al. Time course for the recovery of physical performance, blood hemoglobin, and ferritin content after blood donation. Transfusion. 2015;55:898-905.

7. Bejder J, Andersen AB, Solheim SA, Gybel-Brask M, Secher NH, Johansson PI, et al. Time trial performance is sensitive to low-volume autologous blood transfusion. [Epub ahead of print]. Med Sci Sports Exerc. 2018. https://doi. org/10.1249/MSS.0000000000001837. 
8. Von Rost R, Hollmann W, Liesen $\mathrm{H}$, Schultzen D. Uber den einfluss einer erythrozyten-retransfusion auf die kardio-pulmonale leistungsfahigkeit. Sportarzt u. Sportmed. 1975;26:137-44.

9. Brien AJ, Simon TL. The effects of red blood cell infusion on 10-km race time. JAMA. 1987;257:2761-5.

10. Buick FJ, Gledhill N, Froese AB, Spriet L, Meyers EC. Effect of induced erythrocythemia on aerobic work capacity. J Appl Physiol. 1980;48:636-42.

11. Kanstrup IL, Ekblom B. Blood volume and hemoglobin concentration as determinants of maximal aerobic power. Med Sci Sports Exerc. 1984;16:256-62.

12. Ekblom BT, Berglund B. Effect of erythropoietin administration on maximal aerobic power. Scand J Med Sci Sport. 1991;1:88-93.

13. Ekblom BT, Goldbarg AN, Gullbring B. Response to exercise after blood loss and reinfusion. J Appl Physiol. 1972;33:175-80.

14. Williams MH, Wesseldine S, Somma T, Schuster R. The effect of induced erythrocythemia upon 5-mile treadmill run time. Med Sci Sports Exerc. 1981;13:169-75

15. Turner DL, Hoppeler H, Noti C, Gurtner HP, Gerber H, Schena F, et al. Limitations to VO2max in humans after blood retransfusion. Respir Physiol. 1993;92:329-41.

16. Kots YM, Shcherba MM, Kolker YS, Gorodetskii VD, Sin LD. Experimental study of the relationship between the blood hemoglobin concentration and phyiscal aerobic working capacity. Hum Physiol. 1976;4:43-9.

17. Domen RE. Adverse reactions associated with autologous blood transfusion: evaluation and incidence at a large academic hospital. Transfusion. 1998;38:296-300.

18. World Anti-Doping Agency. The 2018 Prohibited List. Montreal, Quebec: World Anti-Doping Agency; 2017.

19. Chapman RF, Laymon AS, Levine BD. Timing of arrival and preacclimatization strategies for the endurance athlete competing at moderate to high altitudes. High Alt Med Biol. 2013;14:319-24.

20. Robinson BF, Epstein SE, Kahler RL. Circulatory effects of acute expansion of blood volume: studies during maximal exercise and at rest. Circ Res. 1966;XIX:26-33.

21. Williams MH, Goodwin AR, Perkins R, Bocrie J. Effect of blood reinjection upon endurance capacity and heart rate. Med Sci Sports Exerc. 1973;5:181-6.

22. Ekblom BT, Wilson G, Åstrand PO. Central circulation during exercise after venesection and reinfusion of red blood cells. J Appl Physiol. 1976;40:379-83.

23. Bell RD, Card RT, Johnson MA, Cunningham TA, Baker F. Blood doping and athletic performance. Aust J Sport Med. 1976;8:133-9.

24. Williams MH, Lindhjem M, Schuster R. The effect of blood infusion upon endurance capacity and ratings of perceived exertion. Med Sci Sports Exerc. 1978;10:113-8

25. Thomson JM, Stone J, Ginsburg A, Hamilton P. O2 transport during exercise following blood reinfusion. J Appl Physiol Respir Env Exerc Physiol. 1982;53:1213-9.

26. Thomson JM, Stone JA, Ginsburg AD, Hamilton P. The effects of blood reinfusion during prolonged, heavy exercise. Can J Appl Sport Sci. 1983;8:72-8

27. Celsing F, Nystrom J, Pihlstedt P, Werner B, Ekblom B. Effect of long-term anemia and retransfusion on central circulation during exercise. J Appl Physiol. 1986;61:1358-62.

28. Spriet LL, Gledhill N, Froese AB, Wilkes DL. Effect of graded erythrocythemia on cardiovascular and metabolic responses to exercise. J Appl Physiol. 1986;61:1942-8

29. Muza SR, Sawka MN, Young AJ, Dennis RC, Gonzalez RR, Martin JW, et al. Elite special forces: physiological description and ergogenic influence of blood reinfusion. Aviat Space Environ Med. 1987;58:1001-4.

30. Berglund B, Hemmingsson P, Birgegård G. Detection of autologous blood transfusion in cross-country skiers. Int J Sports Med. 1987;8:66-70.

31. Celsing F, Svedenhag J, Pihlstedt P, Ekblom B. Effects of anaemia and stepwise-induced polycythaemia on maximal aerobic power in individuals with high and low haemoglobin concentrations. Acta Physiol Scand. 1987;129:47-54.

32. Sawka MN, Dennis RC, Gonzalez RR, Young AJ, Muza SR, Martin JW, et al. Influence of polycythemia on blood volume and thermoregulation during exercise-heat stress. J Appl Physiol. 1987;62:912-8.

33. Pettitt RW, Clark IE, Ebner SM, Sedgeman DT, Murray SR. Gas exchange threshold and VO2max testing for athletes. J Strength Cond Res. 2013;27:549-55.
34. Ashenden M, Mørkeberg J. Net haemoglobin increase from reinfusion of refrigerated vs. frozen red blood cells after autologous blood transfusions. Vox Sang. 2011;101:320-6.

35. Luten M, Roerdinkholder-Stoelwinder B, Schaap NPM, De Grip WJ, Bos HJ, Bosman GJCGM. Survival of red blood cells after transfusion: a comparison between red cells concentrates of different storage periods. Transfusion. 2008;48:1478-85.

36. Pottgiesser T, Specker W, Umhau M, Dickhuth H-H, Roecker K, Schumacher YO. Recovery of hemoglobin mass after blood donation. Transfusion. 2008:48:1390-7.

37. Juvonen E, Ikkala E, Fyhrquist F, Ruutu T. Autosomal dominant erythrocytosis caused by increased sensitivity to erythropoietin. Blood. 1991;78:3066-9.

38. Gaehtgens P, Kreutz F, Albrecht KH. Optimal hematocrit for canine skeletal muscle during rhythmic isotonic exercise. Eur J Appl Physiol Occup Physiol. 1979;41:27-39.

39. Schuler B, Arras M, Keller S, Rettich A, Lundby C, Vogel J, et al. Optimal hematocrit for maximal exercise performance in acute and chronic erythropoietin-treated mice. Proc Natl Acad Sci U S A. 2010;107:419-23.

40. Marty D, Nicholson P, Haas U. Report to the President of the Union Cycliste Internationale. Lausanne: Union Cycliste Internationale; 2015.

41. European Directorate for the Quality of Medicines \& HealthCare of the Council of Europe. Component monographs. Part B. Red cell components. 19th edtition Guid to Prep use Qual Assur blood components. Strasbourg; 2017. p. 289-323.

42. Pottgiesser T, Specker W, Umhau M, Dickhuth HH, Roecker K, Schumacher YO. Recovery of hemoglobin mass after blood donation. Transfusion. 2008:48:1390-7.

43. Page P. Beyond statistical significance: clinical interpretation of rehabilitation research literature. Int J Sports Phys Ther. 2014;9:726-36.

44. Saltin B, Strange S. Maximal oxygen uptake: "old" and "new" arguments for a cardiovascular limitation. Med Sci Sports Exerc. 1992;24:30-7.

45. Joyner MJ, Coyle EF. Endurance exercise performance: the physiology of champions. J Physiol. 2008;586:35-44.

46. Montero D, Lundby C. Regulation of red blood cell volume with exercise training. Compr Physiol. 2018;9:149-64.

47. Lundby C, Montero D, Joyner M. Biology of VO2 max: looking under the physiology lamp. Acta Physiol (Oxf). 2017;220:218-28.

48. Bonne TC, Doucende G, Flück D, Jacobs RA, Nordsborg NB, Robach P, et al. Phlebotomy eliminates the maximal cardiac output response to six weeks of exercise training. Am J Physiol Integr Comp Physiol. 2014;306:R752-60.

49. Bejder J, Bonne TC, Nyberg M, Sjøberg KA, Nordsborg NB. Physiological determinants of elite mountain bike cross-country Olympic performance. [Epub ahead of print]. J Sports Sci. 2018. https://doi.org/10.1080/02640414. 2018.1546546

50. Mørkeberg J, Belhage B, Rasmussen AB, Damsgaard R, Ashenden MJ, Dziegiel $\mathrm{MH}$. Changes in red blood cell volume, plasma volume, and total blood volume after autologous blood collections. Transfusion. 2008:48:1524-6.

51. Levine BD, Lane LD, Buckey JC, Friedman DB, Blomqvist CG. Left ventricular pressure-volume and Frank-Starling relations in endurance athletes. Implications for orthostatic tolerance and exercise performance. Circulation. 1991;84:1016-23.

52. Saltin B, Radegran G, Koskolou MD, Roach RC. Skeletal muscle blood flow in humans and its regulation during exercise. Acta Physiol Scand. 1998;162:421-36.

53. Poole DC, Richardson RS. Determinants of oxygen uptake. Implications for exercise testing. Sports Med. 1997;24:308-20.

54. Mühling J, Dehne MG, Sablotzki A, Hempelmann G. Cerebral blood flow velocity during isovolemic hemodilution and subsequent autologous blood retransfusion. Can J Anesth. 1999:46:550-7.

55. Jones M, Tunstall Pedoe DS. Blood doping - a literature review. Br J Sports Med. 1989;23:84-8.

56. Bassett DR, Howley ET. Limiting factors for maximum oxygen uptake and determinants of endurance performance. Med Sci Sports Exerc. 2000;32:70-84.

57. Coyle EF, Coggan AR, Hopper MK, Walters TJ. Determinants of endurance in well-trained cyclists. J Appl Physiol. 1988;64:2622-30.

58. Spriet LL, Lindinger MI, McKelvie RS, Heigenhauser GJ, Jones NL. Muscle glycogenolysis and $\mathrm{H}+$ concentration during maximal intermittent cycling. J Appl Physiol. 1989;66:8-13. 
59. Böning D, Maassen N, Thomas A, Steinacker JM. Extracellular pH defense against lactic acid in normoxia and hypoxia before and after a Himalayan expedition. Eur J Appl Physiol. 2001;84:78-86.

60. Swietach P, Tiffert T, Mauritz JMA, Seear R, Esposito A, Kaminski CF, et al. Hydrogen ion dynamics in human red blood cells. J Physiol. 2010;588:4995-5014.

61. Juel C, Lundby C, Sander M, Calbet JAL, van Hall G. Human skeletal muscle and erythrocyte proteins involved in acid-base homeostasis: adaptations to chronic hypoxia. J Physiol. 2003;548:639-48.

62. Lopez E-ID, Smoliga JM, Zavorsky GS. The effect of passive versus active recovery on power output over six repeated wingate sprints. Res Q Exerc Sport. 2014;85:519-26.

63. McGawley K, Bishop DJ. Oxygen uptake during repeated-sprint exercise. J Sci Med Sport. 2015;18:214-8.

64. Bogdanis GC, Nevill ME, Boobis LH, Lakomy HK, Nevill AM. Recovery of power output and muscle metabolites following $30 \mathrm{~s}$ of maximal sprint cycling in man. J Physiol. 1995;482(Pt 2):467-80.

65. Hargreaves M, McKenna MJ, Jenkins DG, Warmington SA, Li JL, Snow RJ, et al. Muscle metabolites and performance during high-intensity, intermittent exercise. J Appl Physiol. 1998;84:1687-91.

66. Bogdanis GC, Nevill ME, Boobis LH, Lakomy HK. Contribution of phosphocreatine and aerobic metabolism to energy supply during repeated sprint exercise. J Appl Physiol. 1996;80:876-84.

67. Calbet JAL, Chavarren J, Dorado C. Fractional use of anaerobic capacity during a 30- and a 45-s Wingate test. Eur J Appl Physiol Occup Physiol. 1997;76:308-13.

68. Medbø II, Tabata I. Relative importance of aerobic and anaerobic energy release during short-lasting exhausting bicycle exercise. J Appl Physiol. 1989;67:1881-6.

69. Hogan MC, Richardson RS, Haseler LJ. Human muscle performance and PCr hydrolysis with varied inspired oxygen fractions: a 31P-MRS study. J Appl Physiol. 1999:86:1367-73.

70. Balsom PD, Ekblom B, Sjödin B. Enhanced oxygen availability during high intensity intermittent exercise decreases anaerobic metabolite concentrations in blood. Acta Physiol Scand. 1994;150:455-6.

\section{Publisher's Note}

Springer Nature remains neutral with regard to jurisdictional claims in published maps and institutional affiliations.

\section{Submit your manuscript to a SpringerOpen ${ }^{\circ}$ journal and benefit from:}

- Convenient online submission

- Rigorous peer review

- Open access: articles freely available online

- High visibility within the field

- Retaining the copyright to your article 